Article

\title{
Willingness to Pay for Renovation of Multi-Flat Buildings and to Share the Costs of Renovation
}

\author{
Dalia Streimikiene ${ }^{1, *(\mathbb{D})}$ and Tomas Balezentis ${ }^{2, * \mathbb{D}}$ \\ 1 Lithuanian Energy Institute, Breslaujos 3, LT-44403 Kaunas, Lithuania \\ 2 Lithuanian Institute of Agrarian Economics, A. Vivulskio g. 4A-13, 03220 Vilnius, Lithuania \\ * Correspondence: dalia.streimikiene@lei.lt (D.S.); tomas.balezentis@laei.lt (T.B.)
}

Received: 4 May 2020; Accepted: 24 May 2020; Published: 28 May 2020

\begin{abstract}
The paper deals with the problems linked to the energy renovation of multi-apartment buildings and developed a case study in Lithuania with the aim to assess the household's willingness to pay for energy renovation and to define the main barriers preventing the households from making decisions to renovate their apartments in residential buildings. Energy renovation provides huge energy savings and greenhouse gas emissions reduction potential and though policies and measures exist to promote large scale energy renovation, there are still many barriers and the pace of energy renovation is still very slow, especially in new EU member states and former Soviet Union members. These countries have inherited old, energy inefficient residential buildings from their Soviet past, and their inhabitants are locked in energy poverty because of their inability to renovate their apartments. This paper analyzed the current situation in the selected country and presents the results of a case study on willingness to pay (WTP) for energy renovation in Lithuanian residential buildings. The survey of 104 Lithuanian households living in unrenovated multi-flat buildings was conducted. The 39 multiple choice questions were asked in order to define the main barriers and drivers of energy renovation. The main results of this pilot study indicated that there are several important organizational and economic barriers for energy renovation in multi-flat buildings and current policies and support schemes have not addressed them in a proper way. The high heating bills and low heat comfort in apartments were the main drivers of energy renovation decision-making for households, however, inadequate state support, reluctance to take a loan due to low income, and inability to make collective decisions on renovation due to the lack of cooperation and housing association were the main barriers that prevented them from this step. New innovative schemes like the Energy Service Companies ESCO model with consolidated billing can be applied to address the identified barriers.
\end{abstract}

Keywords: energy; renovation; multi-flat buildings; barriers; willingness to pay; state polices

\section{Introduction}

Though there are huge energy savings in residential buildings in Lithuania, which has a large stock of old and poorly constructed multi-flat buildings, the process of refurbishment is very slow. Lithuania has set ambitious energy and climate targets for 2020, 2030, and 2050. The main directions and measures of energy efficiency improvement have been established in the updated National Energy Independence Strategy, National Climate Change Management Policy Strategy, and integrated into the National Energy and Climate Action Plan of the Republic of Lithuania 2021-2030.

The country has implemented various policies and measures to promote the renovation of multi-flat buildings; however, these measures have not provided the expected results (Streimikiene, Balezentis, 2019 [1]). 
There are several studies that have analyzed the drivers and barriers of energy renovation in Eastern Europe and post-Soviet countries (Dabija, 2010 [2]; Hernández and Bird, 2010 [3]; Herrero, Urge-Vorsatz, 2012 [4]; Boute, 2012 [5]; Bouzarowski, 2013 [6]; Bouzarowski, Petrova, 2015 [7]; Janda et al. 2014 [8]; Labanaca et al. 2015 [9]; Weinsziehr et al. 2017 [10]; etc.), however, there have been no studies addressing these issues in Lithuania. Zoric et al. (2012) [11] stated that the age of the apartment owner was an important barrier, whereas inconvenience was identified as the main barrier by Karvonen (2013) [12]. The under-studied barrier of energy renovation is the failure of owners of multi-apartment buildings to achieve common agreement on the renovation. As most of the studies have been concentrated on the economic barriers of energy renovation and the low incomes of households (Herrero, Urge-Vorsatz, 2012 [4]; Boardman, 2010 [13]), this paper aimed to overcome this gap and analyzed the main drivers and barriers of energy renovation in Lithuania and assessed willingness to pay for energy renovation.

The main input of the paper is the development of a case study to assess willingness to pay for energy renovations in multi-flat buildings and the identification of the main barriers and problems hampering energy renovation in the selected former Soviet Union country and recent EU Member State, Lithuania.

Section 2 presents the literature review; Section 3 introduces the current situation of Lithuania in terms of energy renovation; Section 4 establishes the study framework; Section 5 discusses the results and findings of the conducted case study, and Section 6 presents our conclusions.

\section{Literature Review}

There are several studies dealing with willingness to pay (WTP) for energy efficiency improvements in households. Poortinga et al. (2003) [14], in his study of WTP for energy renovation, analyzed the impact of socio-economic variables and environmental attitudes, while analyzing the United Kingdom (UK) household priorities for efficient heating systems and insulation measures.

Jakob (2006) [15] and Grosche and Vance (2009) [16] examined the influence of social-economic household profile and their property characteristics on the adoption of different efficiency measures in Switzerland and Germany, respectively. These studies also modeled heating system purchase decisions as a function of property and household characteristics, but expanded the set of control variables to include location and home. Michelsen and Madlener (2012) [17] modeled the technologies for renewable heating systems in Germany as well as home and space features to define the WTP for energy efficiency improvements such as education, household composition, and certain property characteristics like type, age, and size. Banfi et al. (2008) [18] and Phillips (2012) [19] used different choice experiments to explore the tenants' preferences for specific combinations of energy efficiency investments in Switzerland and New Zealand, respectively, and received mixed results. For example, Banfi et al. (2008) [18] found that the WTP for Swiss tenants for energy efficiency measures such as window replacement and the installation of a ventilation system was usually higher than the associated investment costs. The study by Wilhelmsson (2002) [20] assessed the average non-marginal WTP for a 25 per cent increase in a given housing attribute level and found that WTP for all renovation attributes were higher for environmentally aware households. On average, environmentally aware households had non-marginal WTP about 2-4\% higher for insulation, solar energy, and waterborne distribution system, etc. In addition, it was found that households with a high income were willing to pay more for all attributes, but the difference between environmentally aware households and those not aware were the same as for all households. The study by Phillips (2012) [19] assessed the willingness to accept rent increases in exchange for energy efficiency improvement of the heating system and showed that while improved comfort played an important role, tenants were not well informed about the financial savings associated with their investments.

Several studies (Glumac et al. 2013 [21]; Hope, 2012 [22]; Galvin, 2014 [23]) have analyzed the irrationality of behavior in specific renovation projects in the Netherlands and other countries and showed that the increase in rents is an important engine of the acceptability of deep energy retrofitting. 
The study by Carroll et al. (2016) [24] showed that information plays an important role in WTP for energy renovation. The other study by Lang and Lance (2018) [25] confirmed these results and found that the tenants' WTP increased with the implementation of a set of informational interventions.

Energy poverty was found to be an important problem due to the low income population living in poorly insulated buildings in Eastern European countries where low-income households in these countries could not afford better housing or renovation upgrades (Hernández and Bird, 2010 [3]; Bouzarovski and Petrova, 2015 [7]). In Germany, the problem of energy poverty has also been observed in recent decades (Herrero, Urge-Vorsatz, 2012 [4]; Weinsziehr et al. 2017 [10]). Therefore, it is necessary to stress that Eastern European countries face additional barriers, and targeted policies and measures are necessary to overcome barriers of energy renovation in these countries (Streimikiene, Balezentis, 2019 [1]).

The main measures to promote the renovation of multi-flat buildings are the following: information dissemination and advice; energy and $\mathrm{CO}_{2}$ taxes; financial incentives; access to capital; and minimum standards. Information dissemination is an important measure in which to overcome information failures, as due to incomplete or asymmetric information, households are reluctant to make decisions on energy renovations, however, for households experiencing energy poverty, this information is not as useful as they are often experiencing other problems. Taxes on energy or $\mathrm{CO}_{2}$ that raise the cost of energy, sending price signals to households to save energy, can also be considered as important measures, however, for low income populations, it does not provide any solutions. Financial incentives such as tax incentives, grants, and soft loans provide some incentives for consumers to renovate their homes, however, these schemes are not always useful for low income populations (Janda, Parag, 2013 [26]). Minimum performance standards or building codes that are widely used to regulate the standards to which buildings must comply also do not provide appropriate initiatives for solutions to the energy poverty problem.

The Energy Supply Companies Obligations (ESCO) scheme requires energy suppliers or utilities to attain energy efficiency improvements in residential and other buildings. The system of ESCO established in the UK obliges energy utilities to achieve energy efficiency improvements in residential buildings. The ESCO scheme was implemented together with the Green Deal arrangement. The main purpose of the Green Deal is to support vulnerable low-income households make energy efficiency improvements by renovating their apartments. The Green Deal, implemented together with the ESCO scheme, provides opportunities for low income households to pay their renovation costs, not upfront, but placing them on their monthly utility energy bills (Christensen et al. 2011 [27]). This also allows low income households to avoid loans in order to pay for their energy renovation costs.

Based on the literature review, there is no clear evidence for the effectiveness of these policies to date $[28-40]$.

\section{Energy Renovation Situation in Lithuania}

The main goals for energy efficiency and housing renovation in Lithuania are detailed in the National Energy Independence Strategy [41], Energy and Climate Action Plan [42], and National Climate Change Management Policy Strategy [43]. These documents set targets for energy efficiency and housing renovations in various detail. Renovation programs for apartment buildings and public buildings must generate 2.67 TWh of energy savings by 2020. At the end of 2016, 2.1 TWh were saved by the end of the 2019 [44]. One of the most serious reasons for inefficient energy consumption in Lithuania is the very poor thermal properties of most public buildings, which require a lot of energy for heating. Energy renovation of multi-flat buildings would save a lot of energy and significantly reduce greenhouse gas emissions, but despite many years of efforts, renovation in Lithuania has not become massive.

By 2020, Lithuania is planning to save about 11 TWh of energy. It is expected that renovation of apartment buildings will provide for 2.7 TWh of energy savings and renovation of public buildings of $0.4 \mathrm{TWh}$. It is also planned to save 2.4 TWh of energy until 2020 by better informing consumers about the 
energy saving opportunities. According to the Energy and Climate Action Plan, the biggest problems related to multi-flat building renovation in Lithuania are the long payback period of the renovation, the lack of Unified Urban Quarterly Renovation Plans, the volatile project flow, and insufficient funds for the renovation [45].

The multi-apartment building renovation (modernization) program, approved in 2015, set energy savings targets for 2020 and aimed to ensure that soft loans and other statutory state support for apartment owners were available to promote apartment owners to implement energy saving measures and develop public information, education and training on energy efficiency issues in buildings, their renovation (modernization) opportunities, and possible energy and cost savings [46].

The results of the multi-apartment building renovation (modernization) program showed that by 2020 , the implemented renovation projects will reach $75 \%$ of the original targets. Many projects are ongoing and scheduled for completion in 2021. Following the implementation of the program, the implementation of the renovation project will have to reach a $19 \%$ surplus, albeit a year later than planned. It can therefore be said that the program is successful, however, the problems still exist.

As part of the multi-apartment house renovation program, more than 300 multi-apartment buildings or 9000 apartments were renovated in Lithuania last year. From 2013, when municipalities were involved in the renovation process to 2019, more than 24,000 apartment buildings or 700,000 apartments were renovated. Detailed quarterly plans combined with mobility plans for the development and renovation of public buildings and infrastructure when planning cities can provide buildings whose useful area could be increased, or where new buildings could be erected, etc. [46].

Renovation, according to detailed quarterly plans, can achieve economies of scale by reducing the cost of renovation and having a positive external impact on other areas. In Lithuania, in most cases, apartment buildings are only partially renovated, as residents independently implement the most important and energy-efficient measures such as the replacement of windows and doors. Meanwhile, performing a complex renovation on the house increases the payback time. The average payback period of one renovation project is over 15 years. Usually, commercial banks in Lithuania provide investment loans for a maximum period of 10 years. As the duration of the loan is shorter than the payback period of the project, commercial banks do not provide such a loan, or the borrower has to find other sources to service the loan as the energy cost savings are not enough [44].

Research in Lithuania has shown that irrational consumer behavior in the field of energy efficiency is widespread, and the general public perception of the importance of energy savings and energy efficiency is not yet fully formed. Additionally, due to their low financial education, energy consumers often misjudge their energy consumption and savings and payback period, and are more inclined to avoid investing and continue to pay more for energy consumption than to take appropriate action. Since 2013, when measures were initiated for the renovation of multi-apartment buildings, although the population has used public investments more actively, it has not been determined whether the attitude of Lithuanian residents to energy efficiency investments has changed.

In Lithuania, energy consumers often do not have enough information and do not know about the existing technologies for energy saving. Insufficient investment in energy efficiency measures can also be attributed to the lack of information that is due to a lack of energy literacy and motivation to acquire it. Residents who are the final beneficiaries of apartment building modernization projects are often unaware of the benefits of introducing energy efficiency measures, and the overall consensus process among apartment building residents can be very lengthy, sometimes that consensus is not reached at all. Residents of apartment buildings in Lithuania, for many other reasons, have low motivation to initiate energy efficiency projects themselves.

More than 1.3 billion LTL will be needed for the renovation of residential buildings in Lithuania during the 2014-2020 programming period. However, given all the sources of funding available on the market including the EU Structural Funds, co-financing for the renovation of multi-apartment buildings is insufficient. From 2014 to 2020, about 2809 million euros were allocated for the renovation of 
apartment buildings, which was later increased to 314 million euros. However, even then, the necessary investments were more than several times higher [46].

Given the total number of apartment buildings that still need to be refurbished, there are a number of areas for improvement in the implementation of the current program. For example, assessing the quality of renovations requires better maintenance, better, and more reliable data on energy use (consumption) for energy efficiency audits, and a wider range of financial support measures to encourage more homeowners to undertake renovations.

\section{The Background for Willingness to Pay (WTP) Study and Framework}

The main energy policy document, the Lithuanian National Energy Independence Strategy, (2018) states that more than $70 \%$ of apartment buildings in Lithuania are currently inefficient in heat consumption and requires deep energy renovation [41].

As most $(66 \%)$ Lithuanians live in multi-apartment buildings and about $96 \%$ of multi-flat apartment buildings in Lithuania were built before 1993, the assessment of renovation barriers and households willingness to pay for energy renovation is crucial in the sense of promoting energy renovation and implementing new innovative schemes to hasten the process as since 2013 in Lithuania, more that 2000 apartment buildings have been renovated or on average 500 buildings are being renovated per year. As there is a total of 35,500 multi-flat buildings in Lithuania requiring energy renovation, if this pace is maintained, all apartment buildings will be renovated in about 65 years $[45,46]$.

Therefore, due to a very slow pace of energy renovation, which satisfies neither the policy makers nor the residents of these buildings, the main drivers and barriers should be identified in order to find better solutions. Assessment of WTP for renovation will provide more insights into the problem.

The main hypotheses were developed for the case study of WTP for the energy renovation of multi-flat buildings in Lithuania.

1. The main organizational barriers of renovation are linked to reaching common agreement on renovation between apartment owners and one body is necessary to take all responsibility for organizational issues linked to the renovation of multi-flat buildings.

2. The main economic barriers of energy renovation are linked with the reluctance to take out loans and the low income of the households.

3. Governmental support for energy renovation is not enough to generate initiatives for the renovation of multi-flat buildings.

4. The WTP for renovation by monthly energy bills have a higher acceptance among households than paying the total costs of renovation upfront before it starts.

5. Low income households are not able to pay for renovations and higher income households are willing to share the costs with them in order to hasten the renovation processes.

The data for WTP assessment were collected in September 2019 by means of a standardized telephone survey $(\mathrm{N}=104)$.

There were 1,321,000 households in Lithuania in 2019 and 792,600 lived in multi-flat buildings. A total of $90 \%$ of these buildings were built up to 1991, therefore 713,340 households lived in old multi-apartment buildings in 2019. In one such type of building, there are on average 60 apartments. As 2430 multi-flat buildings had already been renovated during the 2013-2019 period, therefore 145,800 households lived in renovated apartments and 567,540 households lived in energy inefficient and unrenovated apartments. Therefore, our general sample was 567,540. The sample size ensures the respondents were representing all the major strata of the social status and living conditions.

The survey included 39 multiple choice questions. The questionnaire consisted from several parts: in the first part, the demographic data of the respondents were collected (Table 1); in the second part, the housing conditions were assessed (Table 2); in the third part, the drivers (Tables 3 and 4) and barriers (Table 5) of renovation were identified by asking specific questions; in the fourth part, 
willingness to pay for energy renovation (Table 6) and to share costs with low income neighbors (Table 7) were assessed by providing several multiple choice questions.

Approximately 1000 phone calls were made and the response rate was $10 \%$. The data were obtained by a professional polling agency. Hierarchical sampling was applied in order to guarantee a representative sample from 10 Lithuanian regions based on statistics published by the Statistical Office. The respondents were also screened by multi-family apartment type (built before 1993) and by age (lower threshold was 18 years of age) by taking into account the responsibility of being the head of the household and paying the household's energy bills.

Demographic data of the sample are provided in Table 1.

Table 1. Sample data.

\begin{tabular}{|c|c|c|}
\hline Gender & Frequency & Percent \\
\hline Female & 48 & 46.2 \\
\hline Male & 56 & 53.8 \\
\hline Social status & Frequency & Percent \\
\hline Married & 72 & 69.2 \\
\hline Divorced & 11 & 10.6 \\
\hline Single & 11 & 10.6 \\
\hline Widow & 3 & 2.9 \\
\hline Cohabitants & 7 & 6.7 \\
\hline Age & Frequency & Percent \\
\hline Up to 23 & 3 & 2.9 \\
\hline $23-34$ & 19 & 18.3 \\
\hline $35-44$ & 43 & 41.3 \\
\hline $45-65$ & 34 & 32.7 \\
\hline Above 65 & 5 & 4.8 \\
\hline Work & Frequency & Percent \\
\hline Unemployed & 8 & 7.7 \\
\hline Retired & 4 & 3.8 \\
\hline Employed in public sector & 37 & 35.6 \\
\hline Employed in private sector & 46 & 44.2 \\
\hline Self-employed (Business) & 9 & 8.7 \\
\hline Income per month & Frequency & Percent \\
\hline Less than 300 euros & 10 & 9.6 \\
\hline 300-500 euros & 13 & 12.5 \\
\hline 501-1000 euros & 36 & 34.6 \\
\hline 1001-1500 euros & 24 & 23.1 \\
\hline 1501-2000 euros & 15 & 14.4 \\
\hline 2001-3000 euros & 3 & 2.9 \\
\hline Above 3000 euros & 3 & 2.9 \\
\hline Education & Frequency & Percent \\
\hline Secondary & 10 & 9.6 \\
\hline Higher Education & 14 & 13.5 \\
\hline Tertiary Education & 80 & 76.9 \\
\hline
\end{tabular}

Source: Created by the authors.

As can be seen from the information in Table 1, 46\% of respondents were women and $53.8 \%$ were men. About $70 \%$ of the respondents were married. The majority of households (over $40 \%$ ) were $35-44$ years old, of which only about $8 \%$ were unemployed and about $4 \%$ were retired, while $44.2 \%$ of respondents were employed in the private sector and $35.6 \%$ were employed in the public sector. The majority of respondents ( $34 \%$ ) had a monthly income of between $€ 500$ and $€ 1000$. Only about 
$6 \%$ of households had an income in excess of $€ 2000 /$ month. About $10 \%$ of households had incomes below $€ 300$ per month. Another $14 \%$ of households had incomes ranging from $€ 1500$ to $€ 2000 /$ month. As many as $77 \%$ of households had a tertiary education.

The housing conditions are addressed in Table 2.

Table 2. Housing information.

\begin{tabular}{|c|c|c|}
\hline Indicator & Frequency & Percent $\%$ \\
\hline \multicolumn{3}{|c|}{ Size of household } \\
\hline 1 Person & 5 & 4.8 \\
\hline 2 Persons & 33 & 31.7 \\
\hline 3 Persons & 29 & 27.9 \\
\hline 4 Persons & 31 & 29.8 \\
\hline 5 Persons & 6 & 5.8 \\
\hline \multicolumn{3}{|c|}{ Type of house } \\
\hline Brick House & 12 & 11.5 \\
\hline Block House & 92 & 88.5 \\
\hline \multicolumn{3}{|c|}{ Year of house construction } \\
\hline Up to 1961 & 13 & 12.5 \\
\hline $1962-1993$ & 90 & 86.5 \\
\hline After 2010 & 1 & 1.0 \\
\hline \multicolumn{3}{|c|}{ Size of apartment } \\
\hline Less than $20 \mathrm{~m}^{2}$ & 4 & 3.8 \\
\hline $20-50 \mathrm{~m}^{2}$ & 40 & 38.5 \\
\hline $51-70 \mathrm{~m}^{2}$ & 40 & 38.5 \\
\hline $71-100 \mathrm{~m}^{2}$ & 20 & 19.2 \\
\hline \multicolumn{3}{|c|}{ Number of rooms in apartment } \\
\hline 1 Room & 2 & 1.9 \\
\hline 2 Rooms & 7 & 6.7 \\
\hline 3 Rooms & 52 & 50.0 \\
\hline 4 Rooms & 42 & 40.4 \\
\hline 5 Rooms & 1 & 1.0 \\
\hline \multicolumn{3}{|c|}{ Number of floors in building } \\
\hline 4 Floors & 30 & 28.8 \\
\hline 5 Floors & 53 & 51.0 \\
\hline 9 Floors & 21 & 20.2 \\
\hline \multicolumn{3}{|c|}{ Ownership of apartment } \\
\hline Private & 73 & 70.2 \\
\hline Rented & 31 & 29.8 \\
\hline \multicolumn{3}{|c|}{ Decision making on renovation } \\
\hline Alone & 25 & 24.0 \\
\hline In consultation & 79 & 76.0 \\
\hline \multicolumn{3}{|c|}{ Availability of housing association } \\
\hline Yes & 46 & 44.2 \\
\hline No & 56 & 53.8 \\
\hline Don't Know & 2 & 1.9 \\
\hline \multicolumn{3}{|c|}{ Energy labeling class } \\
\hline $\mathrm{C}$ & 1 & 1.0 \\
\hline $\mathrm{D}$ & 10 & 9.6 \\
\hline I Don't Know & 93 & 89.4 \\
\hline
\end{tabular}

Source: Created by the authors. 
Table 3. Drivers of energy renovation.

\begin{tabular}{|c|c|c|}
\hline Indicator & Frequency & Percent \\
\hline \multicolumn{3}{|c|}{ Average monthly bill electricity (Cold season) } \\
\hline From 0 to 20 euros & 4 & 3.8 \\
\hline From 21 to 50 euros & 60 & 57.7 \\
\hline From 51 to 100 euros & 32 & 30.8 \\
\hline 101 to 200 euros & 4 & 3.8 \\
\hline 201 to 300 euros & 1 & 1.0 \\
\hline From 301 to 400 euros & 3 & 2.9 \\
\hline \multicolumn{3}{|c|}{ Average monthly bill electricity (Warm season) } \\
\hline From 0 to 20 euros & 16 & 15.4 \\
\hline From 21 to 50 euros & 53 & 51.0 \\
\hline From 51 to 100 euros & 31 & 29.8 \\
\hline 101 to 200 euros & 4 & 3.8 \\
\hline \multicolumn{3}{|c|}{ Monthly heating bill (Cold season) } \\
\hline From 0 to 20 euros & 2 & 1.9 \\
\hline From 21 to 50 euros & 7 & 6.7 \\
\hline From 51 to 100 euros & 34 & 32.7 \\
\hline 101 to 200 euros & 52 & 50.0 \\
\hline 201 to 300 euros & 8 & 7.7 \\
\hline From 301 to 400 euros & 1 & 1.0 \\
\hline \multicolumn{3}{|c|}{ Monthly heating bill (Warm season) } \\
\hline From 0 to 20 euros & 53 & 51.0 \\
\hline From 21 to 50 euros & 40 & 38.5 \\
\hline From 51 to 100 euros & 8 & 7.7 \\
\hline 101 to 200 euros & 2 & 1.9 \\
\hline 201 to 300 euros & 1 & 1.0 \\
\hline \multicolumn{3}{|c|}{ Satisfaction with heat comfort } \\
\hline No & 94 & 90.4 \\
\hline Yes & 10 & 9.6 \\
\hline \multicolumn{3}{|c|}{ Satisfactions with heating expenditures and their matching to heating comfort } \\
\hline No & 104 & 100.0 \\
\hline \multicolumn{3}{|c|}{ Considered renovation } \\
\hline Yes & 95 & 91.3 \\
\hline No & 9 & 8.7 \\
\hline Information about state support & Frequency & Percent \\
\hline Yes & 104 & 100.0 \\
\hline Adequacy of state support & Frequency & Percent \\
\hline No & 104 & 100.0 \\
\hline \multicolumn{3}{|c|}{ Encouragement to renovate due to state support } \\
\hline Yes & 1 & 1.0 \\
\hline No & 89 & 85.6 \\
\hline I Don't Know & 14 & 13.5 \\
\hline \multicolumn{3}{|c|}{ Do you think it is necessary to renovate your apartment? } \\
\hline Yes & 100 & 96.2 \\
\hline No & 2 & 1.9 \\
\hline Don't Know & 2 & 1.9 \\
\hline \multicolumn{3}{|c|}{ Do you have any renovation in your multi-flat apartment at all? } \\
\hline No & 58 & 55.8 \\
\hline Windows were changed & 10 & 9.6 \\
\hline Doors were changed & 27 & 26.0 \\
\hline Roof insulation & 9 & 8.7 \\
\hline
\end{tabular}

Source: Created by the authors. 
Table 4. Average monthly energy cost per $\mathrm{m}^{2}$ taking into account the average apartment size of $53.3 \mathrm{~m}^{2}$.

\begin{tabular}{ccc}
\hline Indicator & euro/month & euro/m $\mathbf{m}^{\mathbf{2}}$ \\
\hline The average monthly bill for electricity during cold season & 62 & 1.16 \\
The average monthly bill for electricity during warm season & 48 & 0.90 \\
The average monthly bill for heating during cold season & 125 & 2.35 \\
The average monthly bill for heating during warm season & 30 & 0.56 \\
The average monthly costs electricity and heating & 152 & 2.85 \\
\hline
\end{tabular}

Source: Created by the authors.

Table 5. Barriers of energy renovation.

\begin{tabular}{ccc}
\hline Indicator & Frequency & Percent \% \\
\hline The main barriers preventing energy renovation \\
\hline High costs of renovation & 2 & 1.9 \\
Low income & 7 & 6.7 \\
The absence of household's association in multi-flat building & 57 & 54.8 \\
I don't want to take a loan which is necessary & 35 & 33.7 \\
The lack of information about possibilities & 2 & 1.9 \\
I am willing to sell my apartment and do not want to invest & 1 & 1.0 \\
\hline Will availability of one responsible for all organization issues linked to renovation have impact on your \\
\multicolumn{4}{c}{ decision to renovate? } \\
Yes No & 97 & 93.3 \\
Don't Know & 5 & 4.8 \\
\end{tabular}

Source: Created by the authors.

Table 6. Willingness to pay for energy renovation.

\begin{tabular}{|c|c|c|}
\hline Indicator & Frequency & Percent \% \\
\hline \multicolumn{3}{|c|}{ WTP for renovation per month in case of $40 \%$ energy saving achieved after } \\
\hline Less than 10 euros & 48 & 46.2 \\
\hline 11 to 50 euros & 44 & 42.3 \\
\hline 51 to 100 euros & 12 & 11.5 \\
\hline \multicolumn{3}{|c|}{ WTP for renovation before starting it in case of $40 \%$ of energy saving achieved after } \\
\hline Less than 1000 euros & 5 & 4.8 \\
\hline 1001 to 2000 euros & 10 & 9.6 \\
\hline 2001 to 3000 euros & 64 & 61.5 \\
\hline 3001 to 4000 euros & 10 & 9.6 \\
\hline 4001 to 5000 euros & 13 & 12.5 \\
\hline Above 5000 euros & 2 & 1.9 \\
\hline \multicolumn{3}{|c|}{ WTP for renovation if costs are included in monthly energy bill in case of $40 \%$ energy saving } \\
\hline $0 \%$ & 2 & 1.9 \\
\hline Up to $10 \%$ increase in my energy bill & 5 & 4.8 \\
\hline $10-20 \%$ increase in my energy bill & 3 & 2.9 \\
\hline $21-30 \%$ increase in my energy bill & 6 & 5.8 \\
\hline $31-40 \%$ increase in energy bill & 28 & 26.9 \\
\hline $41-50 \%$ increase in energy bill & 16 & 15.4 \\
\hline $51-60 \%$ increase in energy bill & 21 & 20.2 \\
\hline $61-70 \%$ increase in energy bill & 15 & 14.4 \\
\hline $71-80 \%$ increase in energy bill & 3 & 2.9 \\
\hline $91-100 \%$ increase in energy bill & 1 & 1.0 \\
\hline Above $100 \%$ & 4 & 3.8 \\
\hline \multicolumn{3}{|c|}{ Preferences of payment for renovation } \\
\hline Total sum & 10 & 9.6 \\
\hline Monthly energy bill & 94 & 90.4 \\
\hline
\end{tabular}

Source: Created by the authors. 
Table 7. Willingness to share renovation costs with lower income neighbors.

\begin{tabular}{|c|c|c|}
\hline Indicator & Frequency & Percent $\%$ \\
\hline \multicolumn{3}{|c|}{$\begin{array}{c}\text { Do you know in your multi-flat apartment the households that are unable to pay for the renovation of } \\
\text { their apartment? }\end{array}$} \\
\hline Yes & 104 & 100.0 \\
\hline \multicolumn{3}{|c|}{ Do you communicate with your house neighbors? } \\
\hline Yes & 13 & 12.5 \\
\hline No & 90 & 86.5 \\
\hline Don't know & 1 & 1.0 \\
\hline \multicolumn{3}{|c|}{ If you do not communicate why not? } \\
\hline I am not satisfied with such neighbors & 28 & 26.9 \\
\hline We do not have anything in common & 64 & 61.5 \\
\hline Other & 12 & 11.5 \\
\hline \multicolumn{3}{|c|}{$\begin{array}{l}\text { Do you accept sharing renovation costs with your neighbors with a lower income and are not able to pay for } \\
\text { renovations of their apartments in multi-flat buildings if your own renovation costs will increase by: }\end{array}$} \\
\hline $0 \%$ & 92 & 88.5 \\
\hline Up to $5 \%$ & 8 & 7.7 \\
\hline $6-10 \%$ & 2 & 1.9 \\
\hline $21-30 \%$ & 2 & 1.9 \\
\hline \multicolumn{3}{|c|}{$\begin{array}{l}\text { Do you accept that neighbors with a higher income will cover the share of your renovation costs if you cannot affor } \\
\text { to pay all sums necessary for your apartment? }\end{array}$} \\
\hline Yes & 104 & 100.0 \\
\hline
\end{tabular}

As one can see from Table 2, households consisting of two, three, and four persons accounted for a similar share, which was about $30 \%$ of all households. One person households accounted for only $5 \%$ of all respondents. The majority of the surveyed households $(89 \%)$ lived in multi-flat apartment buildings, of which as many as $87 \%$ were built in 1961-1993. A total of $90 \%$ of respondents lived in 3-4-room apartments. An equal share of respondents (-40\%) lived in apartments of $20-50 \mathrm{~m}^{2}$ and $51-70 \mathrm{~m}^{2}$ in size. More than $50 \%$ of households lived in five story buildings.

More than $70 \%$ of households owned their apartments. Only $40 \%$ of households lived in multi-apartment buildings with housing associations. The latter indicator suggests that renovation can be problematic in many apartment buildings due to administrative barriers.

The vast majority of respondents $(90 \%)$ did not know the energy class of their house. This shows that it is important to develop a certification of buildings in Lithuania. More than $70 \%$ of respondents made decisions with regard to renovation in consultation with other family members.

In next section, a discussion of the survey results is provided including the assessment of willingness to pay for energy renovation and to share the costs of energy renovation with low income neighbors.

\section{Discussion}

The main drivers and barriers of renovation summarized from the survey are analyzed in Tables 3 and 4 .

As can be seen from the data presented in Table 3, in the cold season, about $60 \%$ of households paid between 21 and 50 euro/month and over 30\% paid from 51 to 100 euro/month for electricity, and in the warm season, $51 \%$ of respondents paid from 21 to 50 euro/month and 30\% from 51 to 100 euro/month.

Meanwhile, in the cold season, as many as $50 \%$ of the surveyed households paid on average 101-200 euro/month for heating and 33\% of the respondents from 51 to 100 euro/month. In the warm season, $51 \%$ paid up to 20 euro/month and $39 \%$ of respondents paid for heating from 21 to 50 euro/month. 
Household electricity costs did not change when comparing the cold and warm periods: in both cases, more than $50 \%$ of respondents stated that the cost of electricity was $21-50$ euro/month. Heating costs increased from 21 to 50 euro/month in most of the households surveyed in the warm period (51\%) to $101-200$ euro/month in the cold period $(50 \%)$. The majority $(57 \%)$ of respondents stated that the average cost of energy was 1010-200 euro/month. In order to estimate the changes in costs and the ratio to the area of apartments, the grouped data were used to calculate the averages of the variables. The average area of the respondents' apartments was $53.3 \mathrm{~m}^{2}$ and in the cold season, the total energy costs of one household amounted to 187 euro/month, and in the warm season from 77 euro/month. The costs per $\mathrm{m}^{2}$ are given in Table 4 .

As can be seen from the figures provided in the tables, heating costs in Lithuania are very high compared to the monthly income of households, and as many as $90 \%$ of households were not satisfied with the thermal comfort of their apartments, and $100 \%$ of respondents stated that heating bills did not correspond to the thermal comfort of their homes. Additionally, over $90 \%$ of respondents considered housing renovation options, but did not use them. Over $90 \%$ of respondents believed that their home needed renovation: $10 \%$ of households replaced windows, $26 \%$ of households replaced exterior doors, and $9 \%$ of households had their roof repaired. A total of $56 \%$ of households had not undergone any partial renovation. As can be seen from Table 3, although all respondents said that they had enough information about state support for apartment building renovations, as many as $85 \%$ of respondents said that the state support did not motivate them to renovate their housing.

Therefore, the main barriers of renovation are identified in Table 5.

The main obstacles to renovation identified by the population (55\%) were the absence of a household community and the reluctance to take out a loan for housing renovation, which households cannot do without (35\%). More than $90 \%$ of respondents thought that the availability of one body taking on all responsibility for the renovation of multi-flat building would have an impact on their decision to start renovations on their apartment.

Assessment of willingness to pay for renovation is given in Table 6 .

As one can see from Table $6,46 \%$ of the surveyed households were willing to pay up to 10 euro/month for housing renovations and $42 \%$ of respondents from 11 to 50 euro/month.

Meanwhile, $61 \%$ of the respondents' WTP for the whole renovation was in the range between 2001 and 3000 euros; $10 \%$ of the respondents' WTP for the energy renovation was in the range between 1001 and 2000 euros; $10 \%$ of respondents were willing to pay from 3001 to 4000 euros; and $12 \%$ of the surveyed respondents were willing to pay from 4001 to 5000 euros.

A total of $27 \%$ of the respondents' WTP for energy renovation, if the renovation costs were distributed and included in their monthly heating bills, was in the range between 31 and $40 \%$ of the increased monthly heating bill; $15 \%$ of households' WTP for housing renovation was in the range between 41 and $60 \%$ of the increased monthly heating bill; $20 \%$ of the households' WTP was from 51 to $60 \%$ of the increased monthly heating bill; and 14\% of respondents' WTP was from 61 to $70 \%$ of the increased monthly heating bill. Given that the average heating bill in the cold season is about 155 euro/month (Table 4), the WTP for energy renovation of the surveyed households in Lithuania to pay for housing renovation under such a financing scheme is quite high and is about 55 euro/month.

It is also necessary to stress that over $90 \%$ of households would choose to pay for energy renovation by including renovation costs in their monthly heating bills. Only about $10 \%$ of the surveyed households would like to pay for the full costs of energy renovation immediately before initiating renovation. In Table 7, the results of the willingness to share renovation costs with lower income neighbors are presented.

All respondents admitted that their apartment building was inhabited by households who could not afford to renovate their apartments by themselves, but almost $90 \%$ of respondents did not express a desire to share renovation costs with poorer neighbors and cover part of their renovation costs, thus speeding up the whole building's renovation process, although, all respondents agreed to accept help from other households to cover part of their renovation costs. 
Over $90 \%$ of respondents admitted that the presence of one responsible person or institution who would bear all the organizational costs of renovation would motivate them to renovate their apartments, while as many as $87 \%$ of respondents said that they did not communicate with their neighbors for various reasons like dissatisfactions with the neighborhood (27\%) or the lack of common interests.

Hypotheses 1-4 were not rejected. It was found that the absence of housing association and inability to agree on the decision to renovate the building among households in multi-flat buildings were the main barriers to energy renovation. In addition, over $90 \%$ of respondents thought that the availability of a responsible person or organization that took all responsibility for all organizational issues related to the renovation would influence their decision to renovate their house. Moreover, over $30 \%$ of respondents did not want to take out a loan, which is necessary to pay for the full energy renovation of the building, and over $80 \%$ of respondents thought that the government support did not create adequate incentives to renovate their houses. The study found that $90 \%$ of respondents would prefer to pay for renovation by increasing their heating bills per month, instead of paying the total costs of the renovation.

Hypothesis 5 was rejected as over $90 \%$ of respondents were not willing to share the renovation costs with low-income neighbors.

The performed cross-tabulation indicated that income and gender have an impact on WTP to pay for the full renovation before the starting process. The rest of the demographic variables had no relationship with this WTP. Higher income provided for a higher WTP for renovation. Women also tended to have higher a WTP for renovations.

The ownership and size of the apartment also had an impact on the WTP for the full renovation in total immediately before the starting process. The owners of apartments had a higher WTP for renovation, as did the owners of larger sized apartments.

Work and income had a relationship with the decision to share costs with neighbors who had a lower income. Therefore, the decision to share costs was due to the working situation and income of the respondents and the remaining demographic variables had no relationship. Higher income households were more willing to share the costs of renovation. The participants employed in the private sector tended to have a higher willingness to share renovation costs with low income neighbors.

The results of the study are summarized in Figure 1.

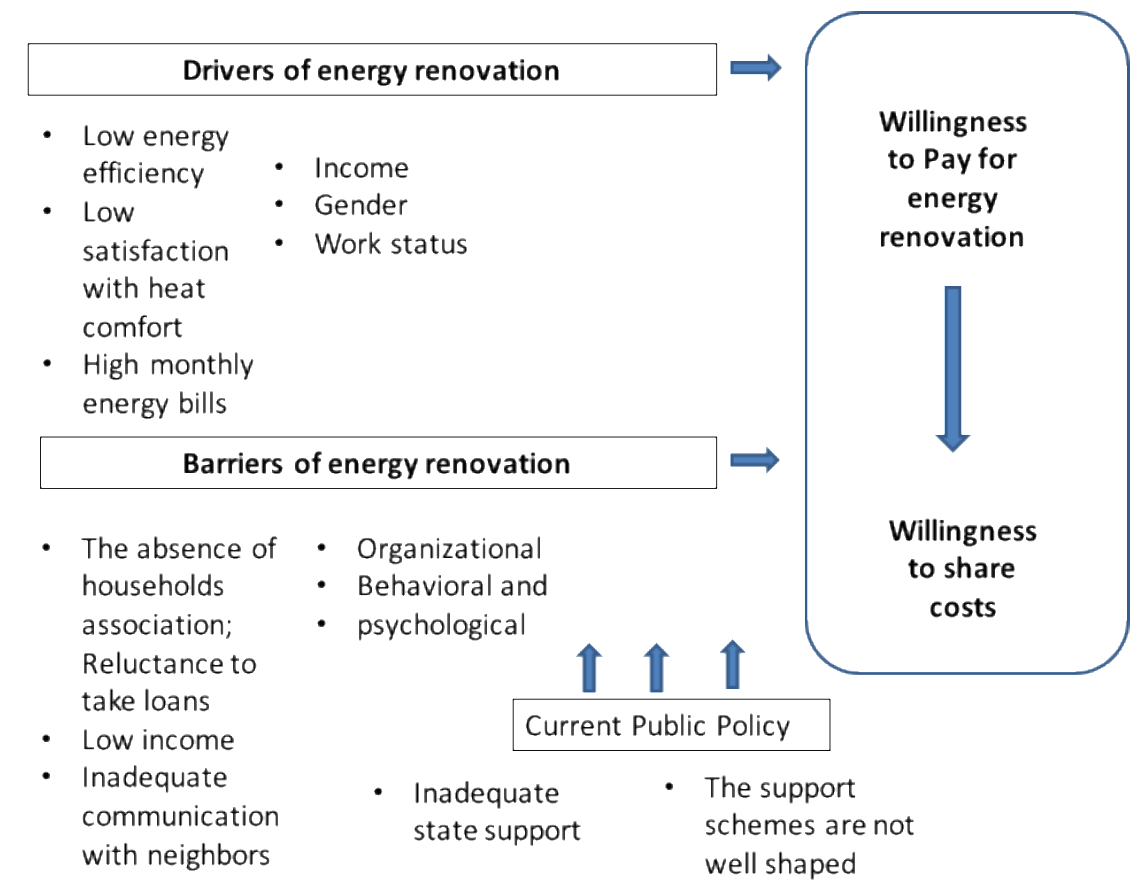

Figure 1. Results of the study. 
As one can see from the summarized results, the study identified the main drivers of the energy renovation of multi-flat buildings and also assessed the impact of demographic characteristics on the willingness to pay for energy renovation. The income, gender, and work status were found to have an impact on WTP.

The survey showed that low heat comfort and high heating bills not corresponding to the heat comfort were the main stimuli for households to start renovations and the significant share of respondents indicated that their house required energy renovation, however, the current state support is inadequate to create initiatives for energy renovation. Nevertheless, the most important barriers of energy renovation in Lithuania are organizational and behavioral. The absence of housing associations and lack of communication between households creates a significant barrier in making decisions on renovations. In addition, the low income of a household and their reluctance to take out loans created additional financial barriers that have also been identified in other studies. Other scholars have identified a variety of interlinked barriers to energy renovation: household values and attitudes [2]; high price [3]; poor organization and inconveniences [4,5]; low-skilled, untrustworthy, or overpriced professionals [8]; and difficulties in making a decision for all apartment homeowners [9]. Several studies have identified similar barriers to the energy renovation of multi-flat buildings: weak political incentives and frequently changing public policies and incentives; lack of appropriate targeted information and household awareness; inadequate motivation of households; major inconveniences; and low affordability $[9,10]$.

The current study did not find a relationship between age and education and WTP for renovation, however, income, ownership, size of apartment, and gender were found to be important drivers of WTP for renovation in Lithuania.

The study found that new policies and measures are necessary to overcome the identified energy renovation barriers in residential buildings. These policies should be better shaped to address barriers identified in the current study: financial, organizational, and behavioral. Innovative policy support schemes like the ESCO model application in the residential sector might be useful as this model allows the three identified barriers to be overcome together: it proposes a consolidated billing approach that is very useful for overcoming financial barriers and provides a solution to organizational barriers by introducing a responsible organization for dealing with all organizational issues of renovation. The behavioral and psychological barriers like limited cognition and decision-making heuristics will also be better addressed by the ESCO model with consolidated billing.

For Lithuanian municipalities, the implementation of the ESCO model, which features a wide variety of designs, can be useful. The UK ESCO model was set up in 2013 to decrease energy consumption and combat fuel poverty [1]. It is possible, based on the example of the UK, to set legal obligations for energy suppliers in municipalities to implement advanced energy efficiency measures in households and to support the energy renovation of multi-flat buildings by making it possible to not to have to pay for renovation costs in advance, but to cover these costs in the monthly utility bills for energy. The ESCO model needs to be adapted to the national circumstances of Lithuania as Lithuania is distinguished by a shrinking and aging society and "empty nest" syndrome. Another specific issue is that the large stock of inefficient multi-apartment buildings usually have one to four room apartments and diverse households in terms of size, income, education, and age. This creates additional problems that need to be addressed.

\section{Conclusions and Policy Implications}

There are many barriers preventing the energy renovation of multi-flat buildings: a lack of access to capital and lack of knowledge as well as split initiatives and the difficulties of households in reaching a collective decision on building renovations due to the difference in incomes, professions, size of apartments, etc.

While other studies of WTP for the energy renovation of multi-apartment buildings have found that income, age, gender, education, ownership of an apartment, and environmental awareness are 
the key factors influencing household WTP for energy renovation, the current study did not find a relationship between age and education and WTP for energy renovation, but income, ownership, apartment size, and gender were identified as important determinants of WTP for energy renovation in Lithuania.

The study on WTP for energy renovation revealed that the absence of a housing association and the inability of neighbors to agree on the renovation of a multi-apartment buildings are the main organizational barriers to energy renovation in residential buildings of Lithuania.

In addition, the study demonstrated that more than $90 \%$ of households believed that a person or organization responsible for all organizational issues related to the energy renovation would have a significant impact on the decisions of households to undertake renovations of their apartment.

The study indicated that state support is not appropriate to initiate the energy renovation of residential buildings as more than $80 \%$ of respondents believed that government support for apartment building renovations was insufficient. More than $30 \%$ of households are reluctant to take a loan for energy renovation;

The results of the survey showed that more than $90 \%$ of respondents would not want to share the renovation costs of their low-income neighbors and thus speed up the renovation processes in this way. This was linked with the context of Lithuania as, in general, the income of households is low, and is too low to cover the costs of the renovations of their lower income neighbors.

An important result of the performed study was the evaluation of WTP for energy renovation of multi-flat buildings. The WTP for energy renovation of surveyed households in Lithuania was about 55 euro/month. It is also necessary to stress that over $90 \%$ of households would choose to pay for energy renovation by including the renovation costs in their monthly heating bills. Only about $10 \%$ of the surveyed households would like to pay for the full costs of energy renovation immediately before initiating renovation.

The main policy implication of the conducted study is the development of the ESCO model for energy renovation in Lithuania. This model will ensure that the costs of renovation will be included in the monthly heating bill, and most importantly, that the energy company will take all responsibilities for organizing the renovation of the multi-apartment building including the negotiation with households and reaching common decisions on energy renovation. The ESCO model would allow three major energy renovation barriers identified in Lithuania to be overcome: lack of capital and reluctance to take out a loan (economic-financial barrier); inability to reach agreement (organizational) among owners of apartments in multi-flat buildings; and behavioral and psychological barriers linked to limited cognition and decision-making heuristics.

The conducted study also has some limitations. Due to the quite limited sample of the study, this research can be treated as a pilot study. More sophisticated techniques like choice experiment should be applied to define WTP for energy renovation. An increased sample and more advanced econometric techniques like Data Envelopment Analysis DEA can allow more robust results to be obtained and to deliver policy recommendations on a more global scale.

Author Contributions: All authors contributed equally to the manuscript. All authors have read and agreed to the published version of the manuscript.

Funding: This research was funded by a grant (No. S-MIP-17-131) from the Research Council of Lithuania.

Conflicts of Interest: The authors declare no conflicts of interest.

\section{References}

1. Streimikiene, D.; Balezentis, T. Innovative Policy Schemes to Promote Renovation of Multi-Flat Residential Buildings and Address the Problems of Energy Poverty of Aging Societies in Former Socialist Countries. Sustainability 2019, 11, 2015. [CrossRef]

2. Dabija, A.-M. Rehabilitation of Mass Dwellings in Romania. A Critical Approach. Sci. Bull. Electr. Eng. Fac. 2010, 10, 40-45. 
3. Hernández, D.; Bird, S. Energy burden and the need for integrated low-income housing and energy policy. Poverty Public Policy 2010, 2, 668-688. [CrossRef] [PubMed]

4. Herrero, S.T.; Urge-Vorsatz, D. Trapped in the heat: A post-communist type of fuel poverty. Energy Policy 2012, 49, 60-68. [CrossRef]

5. Boute, A. Modernizing the Russian district heating sector: Financing energy efficiency and renewable energy investments under the New Federal Heat Law. Pace Environ. Law Rev. 2012, 29, 746-810.

6. Bouzarovski, S. Energy poverty in the European Union: Landscapes of vulnerability. WIREs Energy Environ. 2014, 3, 276-289. [CrossRef]

7. Bouzarovski, S.; Petrova, S. A global perspective on domestic energy deprivation: Overcoming the energy poverty-fuel poverty binary. Energy Res. Soc. Sci. 2015, 10, 31-40. [CrossRef]

8. Janda, K.B.; Killip, G.; Fawcett, T. Reducing Carbon from the "Middle-Out": The Role of Builders in Domestic Refurbishment. Buildings 2014, 4, 911-936. [CrossRef]

9. Labanca, N.; Suerkemper, F.; Bertoldi, P.; Irrek, W.; Duplessis, B. Energy efficiency services for residential buildings: Market situation and existing potentials in the European Union. J. Clean. Prod. 2015, 109, $284-295$. [CrossRef]

10. Weinsziehr, T.; Grossmann, K.; Groger, M.; Bruckner, T. Building retrofit in shrinking and agening cities: A case-based investigation. Build. Res. Inf. 2017, 45, 278-292. [CrossRef]

11. Zoric, J.; Filippini, M.; Hrovatin, N. Determinants of Energy-Efficient Renovation Decisions of Slovenian Homeowners. In Proceedings of the IAEE Conference, Venice, Italy, 9-12 September 2012.

12. Karvonen, A. Towards systemic domestic retrofit: A social practices approach. Build. Res. Inf. 2013, 41, 563-574. [CrossRef]

13. Boardman, B. Fixing Fuel Poverty: Challenges and Solutions; Earthscan: London, UK, 2010.

14. Poortinga, W.; Steg, L.; Vlek, C.; Wiersma, G. Household preferences for energy-saving measures: A conjoint analysis. J. Econ. Psychol. 2003, 24, 49-64. [CrossRef]

15. Jakob, M. Marginal costs, cost dynamics and co-benefits of energy efficiency investments in the residential buildings sector. Energy Policy 2006, 34, 172-187. [CrossRef]

16. Grosche, P.; Vance, C. Willingness to Pay for Energy Conservation and Free-Ridership on Subsidization: Evidence from Germany. Energy J. 2009, 30, 135-153. [CrossRef]

17. Michelsen, C.C.; Madlener, R. Motivational factors influencing the homeowners' decisions between residential heating systems: An empirical analysis for Germany. Energy Policy 2003, 57, 221-233. [CrossRef]

18. Banfi, S.; Farsi, M.; Filippini, M.; Jakob, M. Willingness to pay for energy-saving measures in residential buildings. Energy Econ. 2008, 30, 503-516. [CrossRef]

19. Phillips, Y. Landlords versus tenants: Information asymmetry and mismatched preferences for home energy efficiency. Energy Policy 2012, 45, 112-121. [CrossRef]

20. Wilhelmsson, M. Household Expenditure Patterns for Housing Attributes: A Linear Expenditure System with Hedonic Prices. J. Hous. Econ. 2002, 11, 75-93. [CrossRef]

21. Glumac, B.; Reuvekamp, S.; Han, Q.; Schaefer, W. Tenant participation in sustainable renovation projects: Using AHP and case studies. J. Energy Technol. Policy 2013, 3, 16.

22. Hoppe, T. Adoption of innovative energy systems in social housing: Lessons from eight large-scale renovation projects in The Netherlands. Energy Policy 2012, 51, 791-801. [CrossRef]

23. Galvin, R. Estimating broad-brush rebound effects for household energy consumption in the EU 28 countries and Norway: Some policy implications of Odyssee data. Energy Policy 2014, 73, 323-332. [CrossRef]

24. Carroll, J.; Aravena, C.; Denny, E. Low energy efficiency in rental properties: Asymmetric information or low willingness-to-pay? Energy Policy 2016, 96, 617-629. [CrossRef]

25. Lang, G.; Lanz, B. Energy Efficiency, Information, and the Acceptability of Rent Increases: A Multiple Price List Experiment with Tenants, IRENE Working Paper, No. 18-04; University of Neuchâtel, Institute of Economic Research (IRENE): Neuchâtel, Switzerland, 2018.

26. Janda, K.B.; Parag, Y. A middle-out approach for improving energy performance in buildings. Build. Res. Inf. 2013, 41, 39-50. [CrossRef]

27. Christensen, T.H.; Gram-Hanssen, K.; Adjei, A.; de Best-Waldhober, M. Energy renovation practices in Danish homes: The influence of energy labels on home renovation practices. In Proceedings of the 10th Conference of the European Sociological Association (esa2011): Social Relations in Turbulent Times, Geneva, Switzerland, 7-10 September 2011. 
28. Sorrell, S.; O'Malley, E.; Schleich, J.; Scott, S. The Economics of Energy Efficiency_Barriers to Cost-Effective Investment; Edward Elgar Publishing: Cheltenham, UK, 2004.

29. Uihlein, A.; Eder, P. Towards Additional Policies to Improve the Environmental Performance of Buildings. European Commission Joint Research Centre, Institute for Prospective Technological Studies. JRC Scientific and Technical Reports EUR 23775 EN-2009. Available online: https://core.ac.uk/download/pdf/38614829.pdf (accessed on 12 March 2020).

30. Lujanen, M. Legal challenges in ensuring regular maintenance and repairs of owner-occupied apartment blocks. Int. J. Law Built Environ. 2010, 2, 178-197. [CrossRef]

31. Novikova, A.; Vieider, F.; Neuhoff, K.; Amecke, H. Drivers of Thermal Retrofit Decisions: A Survey of German Single- and Two-Family Houses (CPI Report); Climate Policy Initiative: Berlin, Germany, 2011.

32. Mallaband, B.; Haines, V.; Mitchell, V. Barriers to Domestic Retro t-Learning from Past Home Improvement Experiences; Loughborough University: Leicestershire, UK, 2011.

33. Fawcett, T.; Killip, G.; Janda, K. Building expertise: Identifying policy gaps and new ideas in housing eco-renovation in the UK and France. In Proceedings of the ECEEE 2013 Summer Study, Belambra Les Criques, France, 3-8 June 2013.

34. Killip, G. Products, practices and processes: Exploring the innovation potential for low-carbon housing refurbishment among small and medium-sized enterprises (SMEs) in the UK construction industry. Energy Policy 2013, 62, 522-530. [CrossRef]

35. Killip, G.; Fawcett, T.; Janda, K. Innovation in low-energy residential renovation: Uk and France. Proc. Ice Energy 2014, 167, 117-124. [CrossRef]

36. Burger, V. The assessment of the regulatory and support framework for domestic buildings in Germany from the perspective of long-term climate protection targets. Energy Policy 2013, 59, 71-81. [CrossRef]

37. Galvin, R. Integrating the rebound effect: Accurate predictors for upgrading domestic heating. Build. Res. Inf. 2015, 43, 710-722. [CrossRef]

38. Guerra-Santin, O.; Boess, S.; Konsttantinou, T.; Romero-Herrera, N. Designing for residents: Building monitoring and co-creation in social housing renovation in the Netherlands. Energy Res. Soc. Sci. 2017, 32, 164-179. [CrossRef]

39. Matschoss, K.; Heiskanen, E.; Atanasiu, B.; Kranzl, L. Energy renovation of EU multifamily buildings: Do current policies target the real problems? In Proceedings of the ECEEE 2013 Summer Study, Belambra Les Criques, France, 3-8 June 2013.

40. Streimikiene, D.; Balezentis, T.; Alisauskaite-Seskiene, I.; Stankuniene, G.; Simanaviciene, Z. A Review of Willingness to Pay Studies for Climate Change Mitigation in the Energy Sector. Energies 2019, 12, 1481. [CrossRef]

41. National Energy Independence Strategy, 2018. Available online: http://enmin.lrv.lt/uploads/enmin/documen ts/files/National_energy_independence_strategy_2018.pdf (accessed on 20 March 2020).

42. Lithuanian Ministry of Environment. National Climate Change Management Policy Strategy. Available online: https://am.lrv.lt/lt/veiklos-sritys-1/klimato-kaita/nacionaline-klimato-kaitos-valdymo-politikos-str ategija (accessed on 20 March 2020).

43. Lithuanian Ministry of Environment. Lithuanian Energy and Climate Action Plan. Available online: http://am.lrv.lt/uploads/am/documents/files/KLIMATO\%20KAITA/Integruotas\%20planas/Final\% 20NECP.pdf (accessed on 20 March 2020).

44. Republic of Lithuania. Report on Progress towards National Energy Consumption Objectives of the Republic of Lithuania in 2017. Available online: http://enmin.lrv.lt/uploads/enmin/documents/files/2017m_efektyvum o_pazangos_ataskaita.pdf (accessed on 20 March 2020).

45. KMG. Evaluation of the Use of EU Funds for Housing Renovation. In Summary of the Final Report; KMG: Vilnius, Lithuania, 2017.

46. EPATEE. [Lithuania] Renovation Programme with EU Funding. Available online: www.epatee-toolbox.eu/wp -content/uploads/2018/10/epatee_case_study_lithuania_renovation_programme_with_eu_funding_ok.pdf (accessed on 21 March 2020).

(C) 2020 by the authors. Licensee MDPI, Basel, Switzerland. This article is an open access article distributed under the terms and conditions of the Creative Commons Attribution (CC BY) license (http://creativecommons.org/licenses/by/4.0/). 